\title{
Temporal and spatial changes in the diet of Hyla pulchella (Anura, Hylidae) in southern Uruguay
}

\author{
Raúl Maneyro ${ }^{1,2}$ and Inés da $\operatorname{Rosa}^{1}$ \\ ${ }^{1}$ Sección de Zoología de Vertebrados, Facultad de Ciencias, Universidad de la República. Iguá 4225, 11400, \\ Montevideo, Uruguay E-mail: rmaneyro@fcien.edu.uy. \\ ${ }^{2}$ Laboratório de Herpetologia, Museu de Ciências e Tecnologia \& Faculdade de Biociências da Pontifícia \\ Universidade Católica do Rio Grande do Sul. Av. Ipiranga 6681, 90619-900, Porto Alegre, RS, Brazil.
}

\begin{abstract}
Temporal and spatial changes in the diet of Hyla pulchella (Anura, Hylidae) in southern Uruguay. In this article we report the diet of a population of the hylid frog Hyla pulchella from southeastern Uruguay. We collected the specimens in ponds, where we identified microenvironments defined by the invertebrate assemblage, during one year divided into two seasons (warm and cold). We taxonomically determined 10365 invertebrates belonging to 21 categories in the digestive tracts of frogs. We estimated the diversity of the diet and alimentary preference according to microenvironments and seasons. We estimated the expected richness of both diet and prey availability using a null model based on the hypergeometric distribution. We performed Discriminant Analyses and Kruskal-Wallis tests to detect changes in prey availability among microenvironments and between seasons. The overall diet in terms of frequencies was composed primarily of arthropods (mainly Araneae, Diptera, Hymenoptera, and Coleoptera) and in terms of volume, by larvae. The most relevant items to study the microenvironmental and seasonal variation in the available preys were Araneae, Collembola, Homoptera, Hymenoptera, Diptera, Dictioptera, Lepidoptera, Coleoptera, and larvae. Based on the null model curves and preference indexes we inferred positive selection by larvae, Isopoda, Dictioptera, Lepidoptera, and Diptera, and negative selection by Collembola and Hymenoptera. The diversity of diet and the null model curves indicated that the diet changes among microenvironments and seasons. This frog may be considered as a middle generalist predator, with some selective behavior and a combined search strategy (active and sit-and-wait). We conclude that the knowledge about the availability of preys is a relevant tool for trophic studies.
\end{abstract}

Keywords: Anura, Hylidae, Hyla pulchella, diet, trophic ecology.

\section{Introduction}

Amphibians play a pivotal role linking aquatic and terrestrial ecosystems. However,

Received 27 January 2004

Accepted 18 November 2004.

Distributed December 2004. studies in diets of adult amphibians based on prey availability are scarce, particularly in temperate ecosystems (Hirai and Matsui 1999). Although Schoener (1974) recommended that the study of a trophic niche of species should include the availability of preys, only a few studies have done so (Toft 1980, 1981, Jones 1982, MacNally 1983, Lizana et al. 1986). This 
failure may be significant, due to the potential influence of prey distribution on the feeding behavior the frogs (Labanick 1976, Hirai and Matsui 1999).

An extensive literature has been published about the trophic niche of many Neotropical anurans, although dietary preference were not considered because the environmental availability was unknown (Zug and Zug 1979, Guix 1993, Filipello and Crespo 1994, Lajmanovich 1995, 1996, Teixeira et al. 1999, Brandão et al. 2003, Santos et al. 2003, Teixeira and Vrcibradic 2003, Maneyro et al. 2004). The most extensive works in niche overlap between temperate South American amphibian species are those from Argentinean localities, like Buenos Aires (Basso 1990) and Corrientes (Duré 1999, Duré and Kehr 2001). Recently, Peltzer and Lajmanovich (1999) studied diet variation between two populations of hylid frogs at Santa Fé; da Rosa et al. (2002) analyzed the seasonal changes in the diet of four anuran species in Uruguay. None of the abovementioned works considered prey availability, therefore the observed patterns of prey consumption cannot be explained.

The tree frog Hyla pulchella Duméril and Bibron, 1841 is one of the most common anurans in Uruguay. This species is a middlesized hylid (up to $50 \mathrm{~mm}$ SVL in adult females) that lives in natural wetlands but can also be found in anthropized environments (Achaval and Olmos 2003). This species shows reproductive activity during the whole year in natural or artificial ponds, and the egg clutches are laid in a gelatinous mass attached to aquatic vegetation (Langone 1994). This reproductive mode can be described as Type I (sensu Duellman and Trueb 1994), which means a non-specialized behavior. Bibliographic references indicate that $H$. pulchella is an insectivorous frog, ingesting mainly hymenopterans and dipterans (Gallardo 1987, Basso 1990, Langone, 1994).

The aim of this work was to describe the diet of $H$. pulchella and its variation in three microenvironments and along one year divided into two seasons. We also explored how changes in seasonal and microenvironmental prey availabilities could be reflected in the diet of this frog.

\section{Material and Methods}

Fieldwork was conducted in a private reserve (Reserva Privada de Fauna y Flora "El Relincho") located in southern Uruguay (34'20' S, 57 $00^{\circ}$ 'W) (Figure 1). This area has a temperate climate (average annual temperature 16.6 ${ }^{\circ} \mathrm{C}$, cumulative annual rainfall $1031.6 \mathrm{~mm}$ ) with four seasons. This is a protected area with a management plan that includes the preservation of natural ecosystems with some extensive cattle activities. Many ponds were built in grassland areas several years ago. The specimens (frogs and invertebrate prey) were collected in three of these ponds (Ponds 1, 2, and 3), which were built on the same stream (as a way to minimize environmental variability). In each pond, we identified three microenvironmental categories: straw zone, wet grassland and bank (Figure 2). The straw zone was determined as the place where the pond receives the water supply, characterized by dense vegetation, including mainly Scirpus sp. and Typha sp. The wet grassland covered both margins of the pond; its flora was dominated by grass and aquatic vegetation (Azolla, Polygonum). This location was periodically flooded after heavy rains and thus is characterized by a fluctuating hydric regime. The bank was a sloping artificial grass dam where water retention occurs $(2-3 \mathrm{~m}$ high). These microenvironments were classified to reflect the assemblage of the invertebrates (from here "invertebrate assemblage").

The invertebrate assemblage was estimated through pitfall traps, consisting of $300 \mathrm{ml}$ cans with a solution of liquid soap and $10 \%$ formalin. In all ponds, five traps were placed in each microenvironment, resulting in a design with forty-five traps $\left(5^{\prime} 33^{\prime} 3\right)$. The traps were activated during two successive nights, monthly, from January to December 1998. One of the 


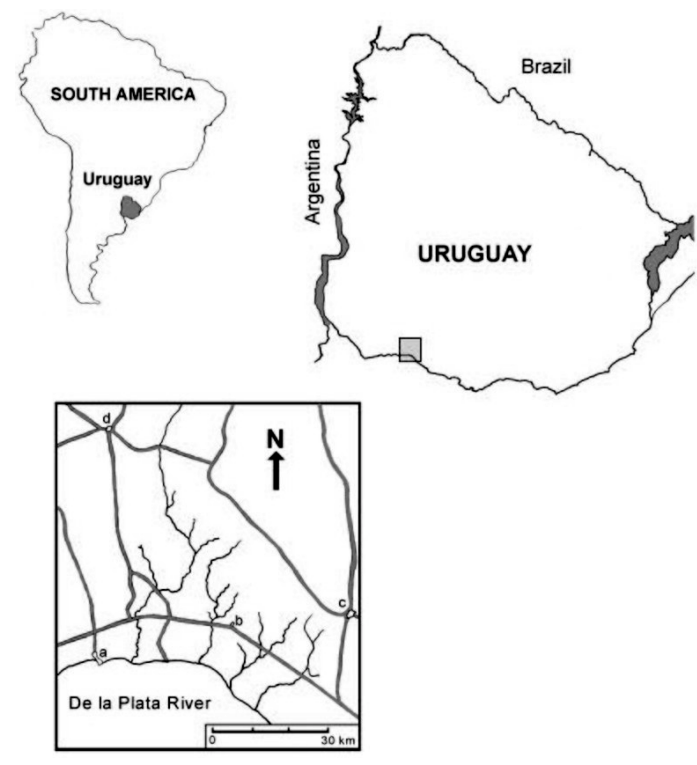

Figure 1 - Study Area. References in the detailed map: a. Juan Lacaze City; b. Ecilda Paulier Town; c. San José de Mayo City; d. Cardona City. Shadded lines represent National routes. Solid lines are rivers and streams.

goals of this study was to verify if zonification based on invertebrate assemblage was consistent with the biophysical architecture of the ponds. To do so, we tested differences among hypothesized microenvironments and ponds by a multivariate analysis of variance (MANOVA) and described them by a Discriminant Analysis (DA). For these analyses the independent variables were the microenvironments (three stages: straw zone, wet grassland, and bank) and the ponds (Ponds 1, 2, and 3). The frequencies in each invertebrate group were the dependent variables (for MANOVA only the variables in the model obtained from the DA were tested). The assumptions of variance homogeneity and normality were tested by the Levenne test and the Shapiro Wilks' W test, respectively.

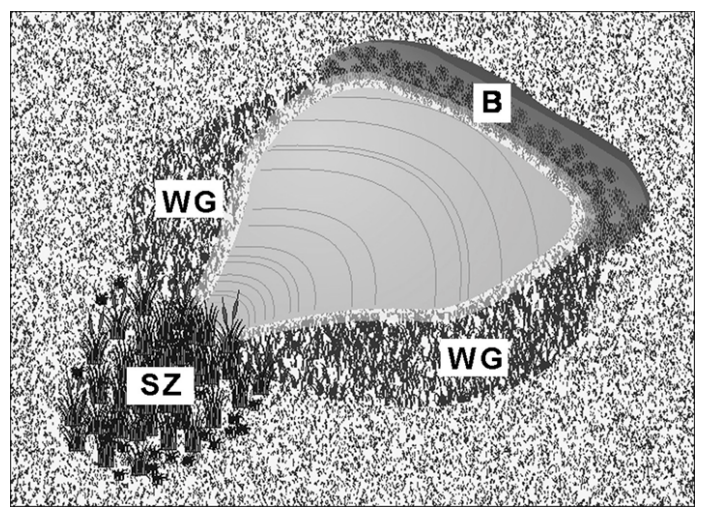

Figure 2 - Schematic representation of one of the ponds. B, bank; WG, wet grassland; SZ, straw zone.

For all statistical and descriptive analysis about the trophic ecology of the frogs, only items in the diet were considered as available prey (named as "available assemblage"), because not all the groups in the invertebrate assemblage are potential preys. The invertebrate assemblage is therefore a good biological descriptor of the microenvironments but it does not reflect the real availability of prey for the frogs (i.e., snails).

Spatial and temporal variation was studied for both prey availability and diet of the frogs. The spatial variation was evaluated within the defined microenvironments (straw zone, wet grassland, bank). The temporal variation was explored by grouping observations as was done in other studies on species of temperate region (da Rosa et al. 2002, Maneyro et al. 2004). Two seasons were defined: a cold season (data collected from April to September, mean temperature below $17^{\circ} \mathrm{C}$ ) and a warm season (from January to March, and October to December, mean temperature above $18^{\circ} \mathrm{C}$ ).

All analyses were performed using the Statistica 5.5 (StatSoft 1999). The set of five traps and two days were grouped as a single observation, resulting in 108 independent replicates (three microenvironments in each of the three ponds during 12 months). 
The frogs were collected during the same period; date, pond number and microenvironment type were recorded. Each frog constituted an independent replicate for the spatial analysis. The anurans were caught by hand and immediately euthanized. All procedures were approved by the Honorary Comission for Animal Experimentation at the University of Uruguay. Specimens were deposited in Vertebrate Zoology Collection, Facultad de Ciencias, Uruguay (ZVCB). The entire alimentary tract was removed in each specimen to obtain individual prey (Schoener 1989). The preys found in each gastrointestinal content were taxonomically determined to Order level recording their frequencies. Taking into account the biases reported by Magnusson et al. (2003), the volume of each prey was estimated by the ellipsoid method proposed by Dunham (1983). Diversity of diet was calculated by the Shannon-Weaver Index (Shannon and Weaver 1949), $H=-S p_{i} x\left(\log p_{i}\right)$, where $p_{i}$ is the proportion of each prey item found in the diet. Dietary preference was calculated by Ivlev Index (Ivlev 1961) II $=\frac{\left(\mathrm{r}_{\mathrm{i}}-\mathrm{n}_{\mathrm{i}}\right)}{\left(\mathrm{r}_{\mathrm{i}}+\mathrm{n}_{\mathrm{i}}\right)}$, where $r_{i}$ is the proportion of each prey item found in the diet and $n_{i}$ is the proportion of each prey item in the available assemblage (from -1 for avoided preys to +1 for preferred preys). Both parameters were calculated for the overall sample and for each microenvironment and season sub-samples.

As the observed richness depends on the total number of observations (Gotelli and Graves 1996), the expected richness for each sample size was estimated using a rarefaction null model (Magurran 1988, Krebs 1989). This model can be applied to calculate the expected richness in several samples for the same sample size (Gotelli and Graves 1996). The model is based on the hypergeometric distribution and the expected values can be calculated as follows: expected richness $=\stackrel{\mathrm{S}}{\sum_{1}}\left(1-\frac{\left(\begin{array}{c}\mathrm{N}-\mathrm{m}_{\mathrm{i}} \\ \mathrm{n}\end{array}\right)}{\left(\begin{array}{c}\mathrm{N} \\ \mathrm{n}\end{array}\right)}\right)$,

where $S$ is the total number of observed items in diet or in available assemblage samples, $\mathrm{N}$ is the total sample size, $\mathrm{m}_{\mathrm{i}}$ is the total number of individuals of the " $i$ " item and $n$ is the sample.

Additional DAs were performed in order to understand the environmental and seasonal changes in the available assemblage and in the consumed prey. The Kruskal-Wallis analysis by items was used as "a posteriori" test (significance at 0.05). To avoid Type 1 error (because of high number of analyzed variables) the alpha value for significant results was corrected by Bonferroni test.

\section{Results}

\section{Microenvironmental Variation of the Invertebrate Assemblage}

A total of 10365 invertebrates were classified into 21 categories including 19 arthropod orders (four Arachnida, two Myriapoda, 11 Hexapoda, and two Crustacea), annelids and insect larvae. Prey availability varied among the three microenvironments, as was suggested by the DA classification (Figure $3)$. The items (variables) included in the model $\left[\mathrm{F}\left({ }_{14.198}\right)=2.35, \mathrm{p}<0.005\right]$ were Hymenoptera, Homoptera, Collembola, Diptera, Acarina, Coleoptera, and Isopoda. This microenvironmental effect was also detected by the MANOVA (Wilks' $1=0.71, \mathrm{~F}=1.93$, df $=$ $18,182, \mathrm{p}=0.02)$. In this analysis, neither pond effect (Wilks' $\mathrm{l}=0.82, \mathrm{~F}=1.07$, df $=18,182$, p $=0.39$ ) nor interaction effect (Wilks' $I=0.72, \mathrm{~F}$ $=0.89$, df $=36,342, \mathrm{p}=0.65$ ) were detected. Therefore, the three ponds were considered as replicates, and the microenvironments, as three treatments. 


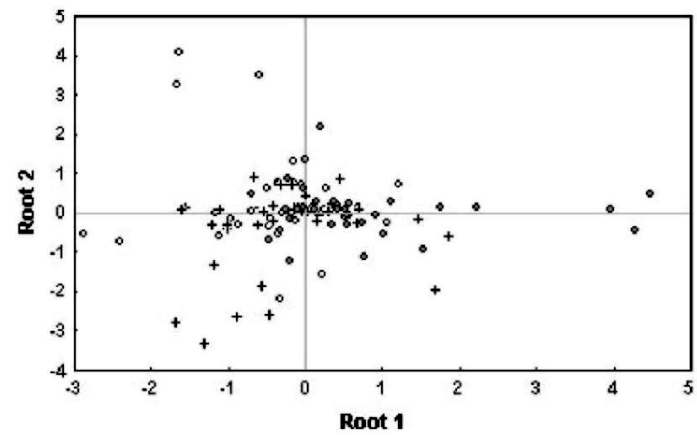

Figure 3 - Graphic representation of the first two roots of the Discriminant Analysis in the environmental availability (Method: Forward Stepwise, F to remove $=0, \mathrm{~F}$ to enter $=1) . \mathrm{F}\left({ }_{14,198}\right)=2.35(\mathrm{p}$ $<0.005)$. Solid circles, bank; Open circles, straw zone; Crosses, wet grassland.
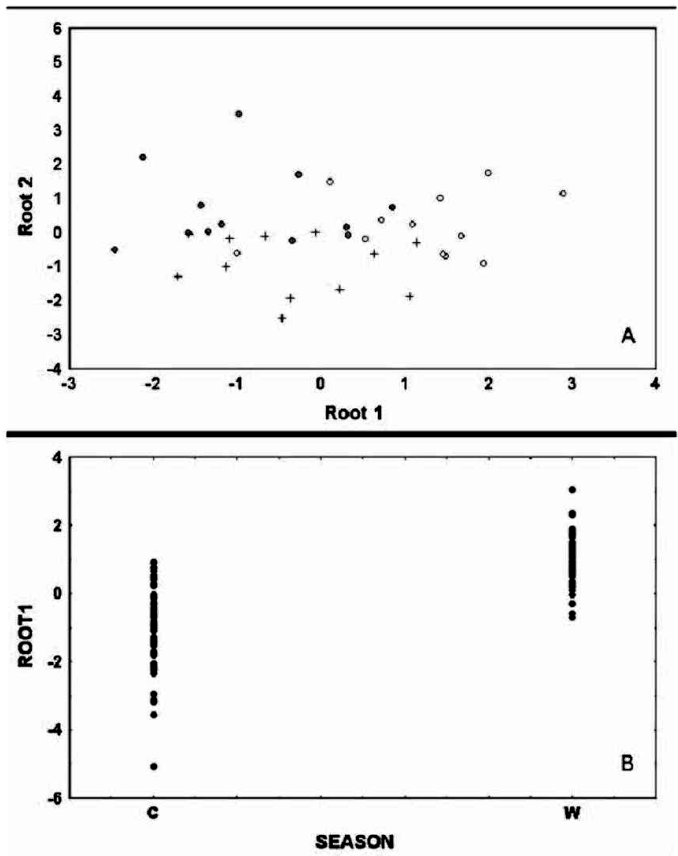

Figure 4 - Graphic representation of the roots of the Discriminant Analysis with available community's data (Method: Forward Stepwise, $\mathrm{F}$ to remove $=0, \mathrm{~F}$ to enter $=1)$. A. first two roots of microenvironmental avaliability's data, $\mathrm{F}\left({ }_{18,50}\right)=1.88(\mathrm{p}<0.004)$. Solid circles, bank; Open circles, straw zone; Crosses, wet grassland. B. the only one extracted root of seasonal avaliability's data, $\left.\mathrm{F}_{8,99}\right)=12.29(\mathrm{p}$ $<0.000$ ). C, cold season; W, warm season.

\section{The Available Assemblage: microenvironmental and seasonal changes}

The available prey assemblage was estimated based on 9543 individuals and included Araneae, Collembola, Orthoptera, Coleoptera, Hymenoptera, Diptera, Lepidoptera, Hemiptera, Homoptera, Dictioptera, larvae, and Isopoda. The most frequent item was Collembola (65.1\%), followed by Hymenoptera $(23.4 \%)$ and Araneae $(6,2 \%)$. The excluded items (present in the invertebrate assemblage) were Scorpiones, Acarina, Opiliones, Chilopoda, Diplododa, Isoptera, Crustacea other than Isopoda, and Annelida. The microenvironments could be distinguished by available prey assemblage $\left[\mathrm{F}\left({ }_{18,50}\right)=1.88, \mathrm{p}<0.04\right]$. Two roots were extracted and graphically presented in Figure 4A, showing these groups (microenvironments). The variables in the model were Araneae, Collembola, Homoptera, Hymenoptera, Diptera, Dictioptera, Lepidoptera, Coleoptera, and larvae. However, none of these taxa showed statistically significant variation in their frequency between microenvironments after the Kruskal-Wallis test (Table 1).

The available assemblage in the warm season differed from that in the cold season (Figure 4B) $\left[\mathrm{F}\left({ }_{8,99}\right)=12.28, \mathrm{p}<0.000\right]$. The variables in the model were Araneae, Collembola, Homoptera, Hymenoptera, Diptera, Dictioptera, Hemiptera, and larvae. Only Araneae and Hymenoptera showed significant differences between seasons by the KruskalWallis test (Table 1).

\section{Overall Diet}

A total of 105 frogs were captured, 35 of which had empty digestive tracts, and 256 prey items were identified. The average number of prey items per individual $(\mathrm{N}=70)$ was $3.66 \pm$ $4.05(\bar{x} \pm \mathrm{SE})$, ranging from 1 to 28 (Table 2 ). Four arthropod orders predominated in number $(82.5 \%)$ in the overall sample. Araneae showed the largest proportion in number, followed by 
Table 1 - Results of the Kruskal-Wallis tests for each variable in the model of the Discriminant Analysis by microenvironment (bank, straw zone, and wet grassland) and by season (warm season: from October to March, cold season: from April to September) for the available community. H, Kruskal-Wallis statistics; df, degree of freedom; p, probability. * indicates significant differences. Alpha values (Bonferroni test corrected) were 0.005 (microenvironmetal analyses) and 0.006 (Seasonal analyses).

\begin{tabular}{lllcccc}
\hline & \multicolumn{3}{c}{ MICROENVIRONMENT } & \multicolumn{3}{c}{ SEASON } \\
\hline & H & df & $\mathbf{p}$ & H & df & p \\
\hline Homoptera & 1.06 & 2 & 0.59 & 2.75 & 1 & 0.10 \\
Lepidoptera & 3.50 & 2 & 0.17 & & & \\
Coleoptera & 0.84 & 2 & 0.66 & & & \\
Larvae & 0.95 & 2 & 0.62 & 2.66 & 1 & 0.10 \\
Collembola & 1.57 & 2 & 0.46 & 1.26 & 1 & 0.26 \\
Hymenoptera & 1.61 & 2 & 0.45 & 26.30 & 1 & $* 0$ \\
Dictioptera & 3.83 & 2 & 0.15 & 4.12 & 1 & 0.04 \\
Araneae & 0.77 & 2 & 0.68 & 3.36 & 1 & $* 0$ \\
Diptera & 0.14 & 2 & 0.93 & 0.19 & 1 & 0.66 \\
Hemiptera & & & & 5.81 & 1 & 0.02 \\
\hline
\end{tabular}

Table 2 - Diet composition of Hyla pulchella in each microenvironment. SZ (straw zone), WG (wet grassland), B (bank), OS (Overall Sample). Total numbers of preys were 91 (SZ), 93 (WG), and 72 (B). Total numbers of frogs were 22 (SZ), 28 (WG), and 20 (B). Total volumes of preys (in $\mathrm{mm}^{3}$ ) were 2611.99 (SZ), 1303.38 (WG), and 1518.90 (B). For the overall sample total number of preys was 256 , total number of frogs was 70 , and total volume of preys was $5434.27 \mathrm{~mm}^{3}$.

\begin{tabular}{|c|c|c|c|c|c|c|c|c|c|c|c|c|}
\hline & \multicolumn{4}{|c|}{ FREQUENCY (\%) } & \multicolumn{4}{|c|}{$\begin{array}{c}\text { NUMERICAL } \\
\text { PROPORTIONS (\%) }\end{array}$} & \multicolumn{4}{|c|}{$\begin{array}{c}\text { VOLUMETRIC } \\
\text { PROPORTIONS (\%) }\end{array}$} \\
\hline & $\mathrm{SZ}$ & WG & B & OS & $\mathrm{SZ}$ & WG & B & OS & $\mathrm{SZ}$ & WG & B & OS \\
\hline \multicolumn{13}{|l|}{ Arachnida } \\
\hline Araneae & 54.5 & 6.7 & 6.0 & 58.6 & 22.0 & 32.3 & 31.9 & 28.5 & 13.4 & 35.2 & 17.0 & 19.6 \\
\hline \multicolumn{13}{|l|}{ Hexapoda } \\
\hline Collembola & & 7.1 & & 2.8 & & 2.2 & & 0.8 & & $<0.1$ & & $<0.1$ \\
\hline Orthoptera & 9.1 & 7.1 & 1.0 & 8.6 & 2.2 & 2.2 & 2.8 & 2.3 & 2.1 & 4.3 & 2.7 & 11.4 \\
\hline Coleoptera & 22.7 & 28.6 & 3.0 & 27.1 & 6.6 & 1.8 & 13.9 & 1.2 & 2.7 & 9.9 & 11.3 & 6.8 \\
\hline Hymenoptera & 13.6 & 21.4 & 1.0 & 15.7 & 37.4 & 1.8 & 2.8 & 18.0 & 2.1 & 3.3 & 0.8 & 2.0 \\
\hline Diptera & 27.3 & 53.6 & 45.0 & 42.9 & 2.9 & 28.0 & 29.2 & 25.8 & 7.6 & 15.1 & 15.4 & 11.6 \\
\hline Lepidoptera & 13.6 & & & 4.3 & 3.3 & & & 1.2 & 19.0 & & & 9.1 \\
\hline Hemiptera & & & 5.0 & 1.4 & & & 2.8 & 0.8 & & & 1.4 & 0.4 \\
\hline Homoptera & & 14.3 & 1.0 & 8.6 & & 4.3 & 4.2 & 2.7 & & 3.8 & 11.1 & 4.0 \\
\hline Dictioptera & 4.5 & 3.6 & & 2.9 & 1.1 & 1.1 & & 0.8 & 1.8 & 9.5 & & 3.2 \\
\hline Larvae & 13.6 & 17.9 & 15.0 & 15.7 & 3.3 & 7.5 & 4.2 & 5.1 & 29.0 & 14.5 & 2.2 & 23.1 \\
\hline \multicolumn{13}{|l|}{ Crustacea } \\
\hline Isopoda & 4.5 & 3.6 & 2.0 & 8.6 & 3.3 & 1.1 & 8.3 & 3.9 & 4.3 & 4.4 & 2.1 & 8.7 \\
\hline
\end{tabular}




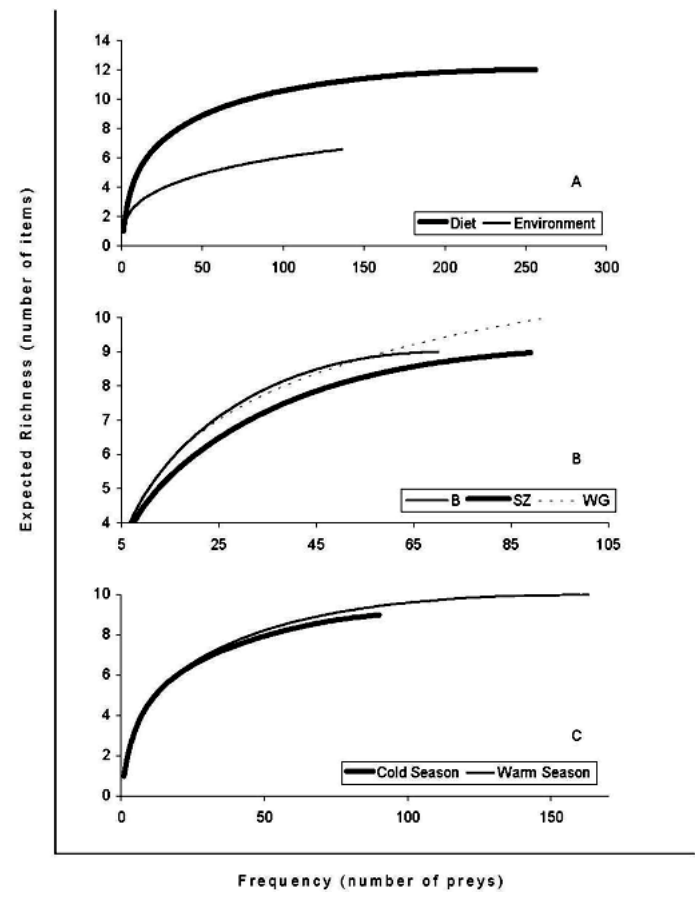

Figure 5 - Graphic representation of rarefaction analysis. (A) Overall sample for diet and environmental availability; (B) diet in each of the three microenvironments, (C) diet in each of the two seasons $($ Cold Season $=$ April to September; Warm Season $=$ October to March).

Diptera, Hymenoptera, and Coleoptera (Table 2). In the volumetrical analysis four invertebrate groups were predominat (65.7\%), larvae (mainly lepidopterans larvae) comprised the largest proportion, followed by Araneae, Diptera, and Orthoptera (Table 2).

The diversity of the diet calculated for the overall sample was 0.82 in frequencies and 0.92 in volume. The rarefaction curve indicated that the maximum expected richness was 12 items (Figure 5). Additionally, this curve showed that the calculated diet of the frog is richer than environmental calculated availability, therefore any kind of selectivity could be occurring. The most preferred preys sensu Ivlev Index were larvae $(\mathrm{II}=0.96)$ followed by Isopoda $(0.95)$, Dictioptera (0.90), Lepidoptera (0.90), and Diptera (0.87). Collembola (-0.98) was the most avoided prey followed by Hymenoptera (-0.13).

\section{Microenvironmental and Seasonal Variation in Diet}

The average numbers of prey items per individual were $4.14 \pm 5.86$ (range $1-28$ ) in the straw zone, $3.32 \pm 2.74(1-12)$ in the wet grassland, and $3.60 \pm 3.25(1-11)$ in the bank ( $F$ $=0.25, \mathrm{df}=2, \mathrm{p}=0.78)$. Araneae was the most frequent category (\%) in the three microenvironments (straw zone $=54.5$, wet grassland $=60.7$, bank $=60.0)$, followed by Diptera $(27.3,53.6,45.0)$ and Coleoptera (22.7, $28.6,30.0)$. In the wet grassland and the bank results for numerical proportions were similar to those observed in frequency. However, the main prey item (highest numerical proportion) in the straw zone was Hymenoptera (37.4), followed by Araneae (22.0) and Diptera (20.9). Taking into account volumetrical proportions, the most consumed item in the straw zone were larvae (29.0), followed by Orthoptera (20.1), and Lepidoptera (19.0). In the wet grassland, the main items were Araneae (35.2), Diptera (15.1), and larvae (14.5), while in the bank were larvae (20.2), Isopoda (20.1), and Araneae (17.0).

The diversity of the diet based in frequencies for each microenvironment was $0.73,0.78$, and 0.77 in straw zone, wet grassland, and bank, respectively; and in volume was $0.80,0.82$, and 0.84. For each microenvironment, the rarefaction curves indicated that the wet grassland was the richest (Figure 5). The bank and the straw zone were similar, but bank was richer than straw zone.

The most preferred preys sensu Ivlev Index at the straw zone were Isopoda (0.93) and Lepidoptera (0.93), at the wet grassland were the larvae (0.97) and Dictioptera (0.94), whereas at the bank were Isopoda (0.98) and Diptera (0.93). When consumed (only at wet grassland), Collembola was the most avoided prey $(-0.98)$, 

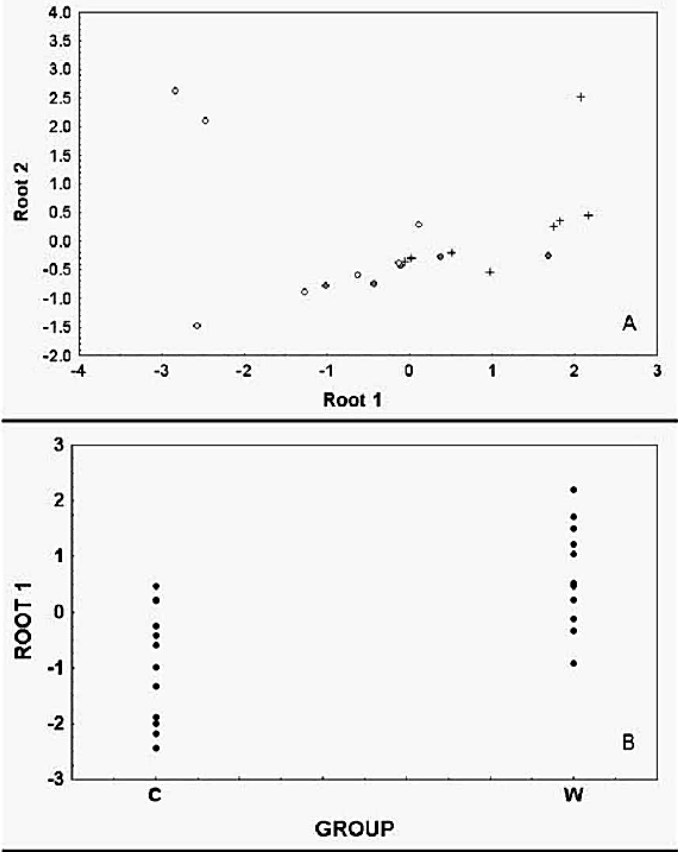

Figure 6 - Graphic representation of the roots of the Discriminant Analysis with the microenvironmental and seasonal variation of consumed preys' data (Method: Forward Stepwise, F to remove $=0, \mathrm{~F}$ to enter $=1$ ). A. first two roots of diet's data by microenvironment, $\mathrm{F}\left({ }_{12,34}\right)=$ 1.33 ( $\mathrm{p}<0.25$ ). Solid circles, bank; Open circles, straw zone; Crosses, wet grassland. B. the only one extracted root of diet's data by season, $F\left({ }_{6,18}\right)=2,63(\mathrm{p}<0.05)$. C, cold season; W, warm season.

followed by Hymenoptera at every microenvironment.

A graphic representation of the DA is shown in Figure 6. The variables in the model were Homoptera, Orthoptera, Lepidoptera, Coleoptera, larvae, and Collembola, but significant differences between groups were not found $\left[\mathrm{F}\left({ }_{12,34}\right)=1.33, \mathrm{p}<0.25\right]$. The significance of each variable in the model was evaluated by Kruskal Wallis test, and no significant differences were found among them (Table 3).
The total number of frogs and preys in each season is given in Table 4 . The average number of prey items per stomach was $3.79 \pm 3.41$ (range 1-11) in the cold season, and $3.59 \pm 4.38$ $(1-28)$ in the warm season $(\mathrm{t}=-0.2, \mathrm{df}=68, \mathrm{p}=$ $0.85)$. Araneae was the most frequent item in both seasons (70.8 and 52.2 respectively in cold and warm season), followed by Diptera (54.2, $37.0)$ and Coleoptera $(29.2,26.1)$. In numerical proportions, the main prey item in the cold season was Araneae (32.6), followed by Diptera (28.9) and Coleoptera (14.1). However, in the warm season the major numerical proportion were showed by Hymenoptera (36.4), followed by Araneae (24.0) and Diptera (22.3). In volumetrical proportions the main item in the cold season were the larvae (35.3), followed by Araneae (24.5) and Isopoda (14.2), whereas in the warm season were Lepidoptera (23.7), Orthoptera (22.3), and Diptera (16.8).

The diversity of the diet calculated in frequencies in each season were 0.74 and 0.77 respectively in cold and warm season, and in volume were 0.73 and 0.89 . The rarefaction curves for each season indicated that the warm season is richer than the cold season (Figure 5).

The most preferred prey sensu Ivlev Index at the cold season were Isopoda and larvae (both reach value 0.98 for the preference Index), followed by Diptera (0.85), Araneae (0.78), and Orthoptera (0.77). At the warm season, the most preferred preys were the larvae $(0.95)$, followed by Lepidoptera (0.92), Diptera (0.90), and Dictioptera (0.88). Collembola was only consumed in the warm season, however, as in the overall analysis, it was the most avoided prey (-0.94). In the case of Hymenoptera, it was avoided along both seasons (-0.86 and -0.07 in cold season and warm season respectively).

Only one root could be extracted from the DA and its distribution between groups (seasons) is shown in Figure 6. The variables in the model were Hymenoptera, Coleoptera, Homoptera, Orthoptera, Lepidoptera and Diptera; significant differences between groups were found $\left[\mathrm{F}\left({ }_{6,18}\right)=2.63, \mathrm{p}<0.05\right]$. No 
Table 3 - Results of the Kruskal Wallis tests for each prey item in the model of the Discriminant Analysis by microenvironment and season. H, Kruskal Wallis statistics; df, degree of freedom; p, probability; * significant differences. Microenvironmental and seasonal analyses (Bonferroni test corrected), alpha $=0.009$.

\begin{tabular}{lllllll}
\hline & \multicolumn{2}{l}{ MICROENVIRONMENT } & \multicolumn{3}{c}{ SEASON } \\
\hline $\mathbf{H}$ & df & $\mathbf{p}$ & $\mathbf{H}$ & $\mathbf{d f}$ & $\mathbf{p}$ \\
\hline Homoptera & 3.04 & 2 & 0.22 & 0.55 & 1 & 0.46 \\
Ortoptera & 0.71 & 2 & 0.70 & 0.49 & 1 & 0.48 \\
Lepidoptera & 2.13 & 2 & 0.35 & 1.08 & 1 & 0.30 \\
Coleoptera & 0.61 & 2 & 0.73 & 4.57 & 1 & 0.03 \\
Larvae & 0.88 & 2 & 0.65 & & & \\
Collembola & 1.78 & 2 & 0.41 & & & \\
Diptera & & & & 0.55 & 1 & 0.46 \\
Hymenoptera & & & & 5.65 & 1 & 0.01 \\
\hline
\end{tabular}

Table 4 - Diet composition of Hyla pulchella in each season. CS, cold season; WS, warm season. Total number of preys $=91(\mathrm{CS})$ and 165 (WS). Total number of frogs $=46$ (CS) and 24 (WS). Total volume of preys $\left(\right.$ in $\left.\mathrm{mm}^{3}\right)=$ $1945.17(\mathrm{CS})$ and $3489.10(\mathrm{WS})$.

\begin{tabular}{|c|c|c|c|c|c|c|}
\hline & \multicolumn{2}{|c|}{ FREQUENCY (\%) } & \multicolumn{2}{|c|}{$\begin{array}{c}\text { NUMERICAL } \\
\text { PROPORTIONS ( } \%)\end{array}$} & \multicolumn{2}{|c|}{$\begin{array}{c}\text { VOLUMETRIC } \\
\text { PROPORTIONS (\%) }\end{array}$} \\
\hline & CS & W S & CS & WS & CS & WS \\
\hline \multicolumn{7}{|l|}{ Arachnida } \\
\hline Araneae & 70.8 & 52.2 & 32.6 & 24.0 & 24.5 & 12.0 \\
\hline \multicolumn{7}{|l|}{ Hexapoda } \\
\hline Collembola & 8.3 & & 1.5 & & $<0.1$ & \\
\hline Orthoptera & 8.3 & 8.7 & 2.2 & 2.5 & 4.6 & 22.3 \\
\hline Coleoptera & 29.2 & 26.1 & 14.1 & 5.8 & 9.2 & 3.1 \\
\hline Hymenoptera & 4.2 & 21.7 & 1.5 & 36.4 & 1.0 & 3.7 \\
\hline Diptera & 54.2 & 37.0 & 28.9 & 22.3 & 8.3 & 16.8 \\
\hline Lepidoptera & & 6.5 & & 2.5 & & 23.7 \\
\hline Hemiptera & & 2.2 & 1.5 & & 0.7 & \\
\hline Homoptera & 4.2 & 10.9 & 3.0 & 2.5 & 2,3 & 6,7 \\
\hline Dictioptera & & 4.3 & & 1.7 & & 8,2 \\
\hline Larvae & 16.7 & 15.2 & 7.4 & 2.5 & 35,3 & 3,7 \\
\hline \multicolumn{7}{|l|}{ Crustacea } \\
\hline Isopoda & 25.0 & & 7.4 & & 14,2 & \\
\hline
\end{tabular}


significant differences were found between groups in the variables in the model (results of Kruskal-Wallis test are showed in Table 3).

\section{Discussion}

An organism can be classified as generalist or specialist depending on the broadness of their trophic niche, whereas to be an opportunist or selective it is related to capture strategies (Jaksic 2001). Hyla pulchella has been considered a generalist species (Basso 1990, da Rosa et al. 2002), as confirmed by the results of this study. However, this species is selective for some of their preys (taking into account availability in the environment). We inferred selectivity from the positive values of the Ivlev Index for some categories (i.e. larvae, Isopoda, Dictioptera, Lepidoptera, Diptera) and the negative values for other categories (i.e. Collembola, perhaps because of their small size, or Hymenoptera, generally ants with formic acid). This result is consistent with other studies including estimates of prey availability (e.g., Toft 1980, 1981). This is in agreement with the rarefaction curves; they showed an expected richness (predicted by the null mode) higher in the diet than in the available assemblage (Figure 5). This fact reaffirms the importance of estimating prey availability when hypothesizing about feeding strategies.

The absence of variation in the diet in the spatial analysis, while the available assemblage differs among microenvironments, could be interpreted as the expression of a selective behavior. However, spatial changes in the availability were detected mainly on the whole analysis, and significant differences by item were not detected.

Considering the temporal analysis, the prey assemblage also differs between seasons. These differences were detected both in the whole analysis and when the items are compared individually. This pattern is reflected in the diet, and in agreement with da Rosa et al. (2002), differences among seasons have been observed.
Seasonal changes have been observed in diet not only in amphibians but also in reptiles (Lizana et al. 1986, Magnusson and Vieira 1993, Feria Ortiz et al. 2001). The seasonal variation indicates that diet of $H$. pulchella could be interpreted as a response to the available assemblage. This pattern has been reported for others frogs (Hirai and Matsui, 1999, 2000, 2001). The diversity of the diet of this species did not vary seasonally, although its diet did so. One of the predictions of the niche overlap hypothesis is that the changes in the axis of the resources could be associated to the presence of other species sharing that resource, minimizing this overlap (Jaksic 2001). The changes observed in the diet of $H$. pulchella may also be related with the presence of other anuran species in the assemblage (Maneyro 2000).

The prey-capture strategies are related with two opposite tactics: opportunistic or selective. A predator that exibits electivity for its prey should look for or wait for the most profitable one from an energetic point of view (Jaksic 2001). Huey and Pianka (1981) proposed that prey type in the diet is correlated with foraging mode of the predators. If the prey is mobile the predator will behave in a sit-and-wait way, while if the prey possesses sedentary habits, then it will be captured by an active predator. The broad diversity of the diet $\left(\mathrm{H}_{\text {frequency }}=0.82\right.$ and $\left.\mathrm{H}_{\text {volume }}=0.92\right)$ and the predominant consumption of Araneae, Coleoptera and Diptera (mediumsized and mobile preys), suggest that $H$. pulchella is a sit-and-wait predator (Toft 1981), as would be expected for a hylid frog (Freed 1980).

On the other hand, the higher consumption of Hymenoptera (mainly ants) during the warm season $(36.4 \%)$ contradicts this pattern, because ants are an aggregated resource and it would imply an active foraging strategy (Toft 1981). In the warm season the frogs ingest hymenopterans in approximately the same proportion as they occur in the environment, but when this item becomes twice as abundant in the available 
assemblage (cold season), it is strongly avoided. Our results do not state whether the frogs search actively for this resource. The leptodactylid Zachaenus parvulus shows a high consumption of ants (Van Sluys et al. 2001) although the leptodactylids belong to the non-ant specialist guild. Perhaps this pattern reflects mixed capture strategies. The ingestion of ants was interpreted historically as a way to incorporate skin toxins for antipredatory functions (Caldwell 1996). In this case, the myrmecophagy may have physiological consequences, as proposed for another hylid, Phyllomedusa hypocondrialis (Peltzer et al. 2000). Another interpretation may be the behavioral consequence of the combined prey search strategy (active and sit-and-wait). This frog may behave as an active forager when it finds an ant nest or trial, like some little leaf litter frogs, such as Dendrobates pumilio (Donnelly 1991) and becoming in that situation, a sit-and-wait predator.

In conclusion, Hyla pulchella presents a generalist diet that responds in great measure to the seasonal variation of the available prey, but with possible trophic interactions with other frogs. This species possesses preference (and then selectivity) for several prey types, probably based on a sit-and-wait strategy of capture.

\section{Acknowledgements}

We are grateful to the colleagues and students of the Sección Zoología Vertebrados (Facultad de Ciencias, UDELAR) for valuable help, especially to Prof. Federico Achaval for logistical support during field and laboratory works. We also thank to Axel Kwet, Catherine Toft and two anonymous reviewers for critical suggestions on the manuscript. To Arley Camargo and Andrés Canavero for suggestions, to Guadalupe Tiscornia and Ronald McGregor for language corrections. Guillermo Macció allowed us to collect and stay at Reserva Privada de Fauna y Flora "El Relincho". RM received a grant from PEDECIBA, Biología and has a doctoral fellowship from Coordenação de
Aperfeiçoamento de Pessoal de Nível Superior (CAPES) at the Pontifícia Universidade Católica do Rio Grande do Sul, Brazil.

\section{References}

Achaval, F. and A. Olmos. 2003. Anfibios y Reptiles del Uruguay. Serie Fauna $\mathrm{N}^{\mathrm{o}} 1$. Montevideo. Barreiro and Ramos. 136 pp.

Basso, N. 1990. Estrategias adaptativas de una comunidad subtropical de anuros. Cuadernos de Herpetología, Serie Monografías 1: 1-70.

Brandão, R. A., A. Garda, V. Braz, and B. Fonseca. 2003. Observations on the ecology of Pseudis bolbodactyla (Anura, Pseudidae) in central Brazil. Phyllomedusa 2: 3-8.

Caldwell, J. P. 1996. The evolution of myrmecophagy in and its correlates in poison frogs (Family Dendrobatidae). Journal of Zoology 240: 75-101.

da Rosa, I., A. Canavero, R. Maneyro, D. Naya, and A. Camargo. 2002. Diet of four sympatric anurans species in a temperate environment. Boletín de la Sociedad Zoológica del Uruguay 13: 12-20.

Donnelly, M. A. 1991. Feeding patterns of the strawberry poison Frog, Dendrobates pumilio (Anura: Dendrobatiae). Copeia 1991: 723-730.

Duellman, W. E. and L. Trueb. 1994. Biology of Amphibians. Maryland. The Johns Hopkins University Press. 670 pp.

Dunham, A. E. 1983. Realized niche overlap, resource abundance and intensity of interspecific competition. Pp: 261-280 in R. D. Huey, E. R. Pianka and T. W. Schoener (eds.), Lizard Ecology. London. Harvard University Press.

Duré, M. 1999. Interrelaciones en los nichos tróficos de dos especies sintópicas de la familia Hylidae (Anura) en un área subtropical de Argentina. Cuadernos de Herpetología 13: 11-18.

Duré, M. I. and A. I. Kehr. 2001. Differential exploitation of trophic resources by two pseudid frogs from Corrientes, Argentina. Journal of Herpetology 35: 340-343.

Feria Ortiz, M, A. Nieto-Montes de Oca and I. H. Salgado Ugarte. 2001. Diet and reproductive biology of the viviparous Lizard Sceloporus torquatus torquatus (Squamata: Phrynosomatidae). Journal of Herpetology 35: 104-112.

Filipello, A. M. and F. A. Crespo. 1994. Alimentación en Melanophryniscus stelzneri (Anura: Bufonidae). Cuadernos de Herpetología 8: 18-24. 
Freed, A. N. 1980. Prey selection and feeding behavior of the Green Treefrog (Hyla cinerea). Ecology 61: 461465 .

Gallardo, J. M. 1987. Anfibios y Reptiles del Partido de Magdalena (Provincia de Buenos Aires). Buenos Aires. Artes Gráficas Rioplatense S.A. 46 pp.

Gotelli, N. J. and G. R. Graves. 1996. Null Models in Ecology. Washington and London. Smithsonian Institution Press. 368 pp.

Guix, J. C. 1993. Hábitat y alimentación de Bufo paracnemis en una región semiárida del nordeste de Brasil, durante el período de reproducción. Revista Española de Herpetología 7: 65-73.

Hirai, T. and M. Matsui. 1999. Feeding habits of the Pond Frog, Rana nigromaculata, inhabiting rice fileds in Kyoto, Japan. Copeia 1999: 940-947.

Hirai, T. and M. Matsui. 2000. Feeding habits of the Japanese Tree Frog, Hyla japonica, in the reproductive season. Zoological Science 17: 977-982.

Hirai, T. and M. Matsui. 2001. Food habits of an endangered Japanese frog, Rana porosa brevipoda. Ecological Research 16: 737-743.

Huey, R. B. and E. R. Pianka. 1981. Ecological consequences of the foraging mode. Ecology 62: 991-999.

Ivlev, V. S. 1961. Experimental Ecology of the Feeding of Fishes. Connecticut. Yale University Press. 302 pp.

Jaksic, F. M. 2001. Ecología de Comunidades. Santiago de Chile. Ediciones Universidad Católica de Chile. $233 \mathrm{pp}$.

Jones, K. L. 1982. Prey patterns and trophic niche overlap in four species of Caribbean frogs. Pp. 49-55 in N. J. Scott Jr. (ed.), Herpetological Communities. Washington. Wildlife Research Report 13.

Krebs, C. J. 1989. Ecological Methodology. New York. Harper Collins Eds. 654 pp.

Lajmanovich, R. 1995. Relaciones tróficas de bufónidos (Anura: Bufonidae) en ambientes del Río Paraná, Argentina. Alytes 13: 87-103.

Lajmanovich, R. 1996. Dinámica trófica de juveniles de Leptodactylus ocellatus (Anura: Leptodactylidae) en una isla del Río Paraná, Santa Fe, Argentina. Cuadernos de Herpetología 10: 11-23.

Langone, J. 1994. Ranas y sapos del Uruguay (Reconocimiento y aspectos biológicos). Intendencia Municipal de Montevideo. Serie Divulgación 5: 1-123.

Lizana, M, M. Ciudad and V. Pérez. 1986. Uso de los recursos tróficos en una comunidad ibérica de anfibios. Revista Española de Herpetología 1: 209-271.

Labanick, G. M. 1976. Prey availability, consumption and selection in the cricket frog, Acris crepitans (Amphibia, Anura, Hylidae). Journal of Herpetology 10: 293-298.
MacNally, R. C. 1983. Trophic relationships of two sympatric species of Ranidella (Anura). Herpetologica 39: $130-140$.

Magnusson, W. E. and E. Vieira da Silva. 1993. Relative effects of size, season and species on the diets of some Amazonian Savanna Lizards. Journal of Herpetology 27: $380-385$.

Magnusson, W. E., A. P. Lima, W. Alves da Silva, and M. Carmozina de Araújo. 2003. Use of geometric forms to estimate volume of invertebrates in ecological studies of dietary overlap. Copeia 2003: 13-19.

Magurran, A. E. 1988. Ecological Diversity and its Measurement. New Jersey. Princeton University Press. 192 pp.

Maneyro, R. 2000. Análisis del nicho trófico de tres especies de anfibios en un grupo de cuerpos de agua lénticos. Unpublished M.Sc. Dissertation. Universidad de la República, Uruguay.

Maneyro, R, D. E. Naya, I. da Rosa, A. Canavero, and A. Camargo. 2004. Diet of the South American frog Leptodactylus ocellatus (Anura, Leptodactylidae) in Uruguay. Iheringia, Série Zoología 94: 57-61.

Peltzer, P. M. and R. C. Lajmanovich. 1999. Análisis trófico en dos poblaciones de Scinax nasicus (Anura, Hylidae) de Argentina. Alytes 16: 84-96.

Peltzer, P, R. Lajmanovich and P. Cacivio. 2000. Diet of Phyllomedusa hypocondrialis azurea Cope 1862 (Anura: Hylidae) in temporary ponds of Chaco, Argentina. Bulletin de la Société Herpétologique de France 93: 5-11.

Santos, J. W. A., R. P. Damasceno and P. L. B. da Rocha. 2003. Feeding habits of the frog Pleurodema diplolistris (Anura, Leptodactylidae) in Quaternary sand dunes of the Middle Rio São Francisco, Bahia, Brazil. Phyllomedusa 2: 83-92.

Schoener, T. W. 1974. Resource partitioning in ecological communities. Science 185: 27-39.

Schoener, T. W. 1989. Should hindgut contents be included in lizards dietary compilations? Journal of Herpetology 23: 455-458.

Shannon, C. E. and W. Weaver. 1949. The Mathematical Theory of Communication. Urbana. University of Illinois Press. 117 pp.

StatSoft, Inc. 1999. STATISTICA for Windows [Computer program manual]. Tulsa, OK. USA. WEB: http:// www.statsoft.com.

Teixeira, R. L. and D. Vrcibradic. 2003. Diet of Leptodactylus ocellatus (Anura, Leptodactylidae) from Coastal Lagoons of Southeastern Brazil. Cuadernos de Herpetología 17: 29-31.

Teixeira, R. L., J. A. P. Schineider and M. Giovanelli. 1999. Diet of the toad Bufo granulosus (Amphibia, 
Bufonidae) from sandy coastal plain in southeastern Brazil. Boletim do Museu de Biologia Prof. Mello Leitão - Nova Série 10: 29-31.

Toft, C. A. 1980. Feeding ecology of thirteen syntopic species of anurans in a seasonal tropical environment. Oecologia 45: 131-141.

Toft, C. A. 1981. Feeding ecology of Panamanian litter anurans: patterns in diet and foraging mode. Journal of Herpetology 15: 139-144.
Van Sluys, M., C. F. D. Rocha and M. B. Souza. 2001. Diet, reproduction and density of the leptodactylid litter frog Zachaenus parvulus in an Atlantic Rainforest of Southeastern Brazil. Journal of Herpetology 35: 322-325.

Zug, G. R. and P. B. Zug. 1979. The marine toad, Bufo marinus: a natural history resumé of native populations. Smithsonian Contributions to Zoology 284: $1-58$. 